\title{
MONITORING EARLY-AGE CONCRETE WITH THE ACOUSTIC-EMISSION METHOD AND DETERMINING THE CHANGE IN THE ELECTRICAL PROPERTIES
}

\author{
PREGLED SVEŽEGA BETONA Z METODO AKUSTIČNE EMISIJE \\ IN DOLOČANJEM SPREMEMB ELEKTRIČNIH LASTNOSTI
}

\author{
Lubos Pazdera ${ }^{1}$, Libor Topolar ${ }^{1}$, Marta Korenska ${ }^{1}$, Tomas Vymazal ${ }^{1}$, \\ Jaroslav Smutny ${ }^{1}$, Vlastimil Bilek ${ }^{2}$ \\ ${ }^{1}$ Brno University of Technology, Faculty of Civil Engineering, Veveri 331/95, 60200 Brno, Czech Republic \\ 2ZPSV a.s., Uhersky Ostroh, Czech Republic \\ pazdera.1@fce.vutbr.cz
}

Prejem rokopisa - received: 2014-07-18; sprejem za objavo - accepted for publication: 2014-11-05

doi:10.17222/mit.2014.112

\begin{abstract}
Concrete is the most popular building composite material (CM). Its long-term aging properties depend on the mixture, the setting and the curing. When concrete is produced and used in the place where we want it to be for the whole of its life, it is very sensitive and easily ruined. Curing is one of the things that we do to keep concrete protected during the first week or so of its life: we maintain proper temperature (neither too hot nor too cold) and dampness. The acoustic-emission method and the electrical-property measurement technique are applied to monitor early-age concrete. The relationships between the acousticemission activity, the temperature and the electrical properties, e.g., the resistivity and the capacity of concrete at an early age were studied in this research. W. Chen et al. studied the microstructure development of hydrating cement pastes during early ages using non-destructive methods including the ultrasound P-wave propagation-velocity measurement and non-contact electrical-resistivity tests. Nevertheless, there are not many references about the continuous study of the properties of concrete during an early age. A long-time monitoring of concrete properties is necessary to determine its lifetime and quality. The acoustic-emission method was proven to be a very advantageous tool for a non-destructive monitoring of structural microchanges during the lifetime of concrete. The differences between hardened concrete mixtures detected with acoustic emission can partly determine their properties at the age of $28 \mathrm{~d}$. The basic concrete property is its compressive strength after $28 \mathrm{~d}$; nevertheless, this can change over a long time period, thus a continuous measuring needs to be applied.
\end{abstract}

Keywords: concrete, acoustic emission, electrical properties, early age, lifetime, curing

Beton je najbolj priljubljen gradbeni kompozitni material (CM). Njegove dolgoletne lastnosti so odvisne od mešanice, položitve in strjevanja. Ko je beton izdelan in ko ga položimo na mesto, kjer naj bi bil do konca trajnostne dobe, je zelo občutljiv in se lahko poškoduje. Strjevanje je ena od stvari, ki zahteva zaščito betona v prvih tednih njegovega trajanja s pravilno temperaturo (niti pretoplo niti prehladno) in vlažnostjo. Metoda akustične emisije in meritve električnih lastnosti so bile uporabljene za kontrolo mladega betona. Preiskovana je bila odvisnost med aktivnostjo akustične emisije in temperaturo, električnimi lastnostmi, kot sta upornost in kapacitivnost mladega betona. W. Chen s sodelavci je študiral razvoj mikrostrukture mlade hidratantne cementne zmesi z neporušnimi metodami, vključno z merjenjem hitrosti napredovanja ultrazvočnih $\mathrm{P}$-valov, in naredil preizkuse brezkontaktne električne upornosti. Vseeno ni veliko literaturnih virov o kontinuirnem spremljanju lastnosti mladega betona. Za določitev zdržljivosti in kvalitete betona je potrebna dolgotrajna kontrola. Metoda akustične emisije se je izkazala kot napredno orodje za neporušno kontrolo mikrosprememb zgradbe med trajnostno dobo betona. Razlike, ugotovljene z akustično emisijo med mešanicami betona pri strjevanju, so delno določile njihove lastnosti po $28 \mathrm{~d}$. Osnovna lastnost betona je 28 -dnevna tlačna trdnost; vendar se ta lahko spreminja v daljšem časovnem obdobju, zato se uporabljajo kontinuirne meritve.

Ključne besede: beton, akustična emisija, električne lastnosti, zgodnja starost, trajnostna doba, strjevanje

\section{INTRODUCTION}

Cement hydration plays a critical role in the temperature development of early-age concrete due to the heat generation ${ }^{1-4}$. It also has significant effects on the material properties and performances at an early age, including material strengths ${ }^{5}$, critical stresses ${ }^{6}$ and distresses like cracking ${ }^{7}$. Therefore, it is essential to capture the hydration property and temperature development of concrete at an early age to prevent premature failures. It is known that the durability of cement-based products and concrete structures is highly influenced by the early stages of hydration ${ }^{8}$. A precise knowledge of the micromechanical properties during the successive phases of the hydration process provides information on the concrete resistance and allows an assessment of its durability $^{9}$. Several non-destructive techniques have been developed and applied in that respect, most of them based on ultrasonic-wave measurements ${ }^{10}$. The recording of passive energy using acoustic-emission techniques was used to evaluate the structural activity in concrete during the early ages, showing periods of intense microstructural changes during the curing process ${ }^{11}$.

Microstructural changes occurring in freshly poured concrete during the curing were monitored on a laboratory scale using a combination of the acoustic-emission technique and the monitoring of electrical properties ${ }^{12}$. The acoustic-emission method is a passive-ultrasonic- 
signal recording technique allowing an online monitoring of the internal microstructural activity of young concrete during the hydration process ${ }^{8}$. The acousticemission technique, which is one of the non-destructive evaluation techniques, is a useful method for investigating local damage in concrete during its lifetime ${ }^{13}$. The micro-changes in concrete structures can be easily estimated, taking account of the number of acoustic-emission hits and counts of the acoustic-emission signal ${ }^{14}$. Acoustic-emission signals are detected, due to microcracks (i.e., structural changes in the material) by the acoustic-emission sensors attached to the surface of a concrete specimen. The acoustic-emission parameters such as the number of hits, counts, duration time, amplitude, energy and rise time are recorded by the acousticemission measurement system ${ }^{15}$.

Impedance spectroscopy, called also dielectric spectroscopy, the monitoring of electrical properties and nuclear-magnetic-resonance spectroscopy have become promising techniques for probing cements and concretes $^{16}$. Cement paste is electrically conductive due to its interconnected pore network filled with an aqueous phase containing mobile ions such as $\mathrm{Na}^{+}, \mathrm{K}^{+}$and $\mathrm{OH}^{-} .{ }^{17}$ Electrical conductivity and resistivity are effective parameters used to monitor the microstructural features of cement-based materials. The electrical conductivity of cement-based materials is dependent on the porosity, the pore connectivity and the conductivity of the pore solution, all of which are significant for the durability of the material $^{18}$. The impedance characteristics and spectra recorded over a wide range of frequencies (if possible from $100 \mathrm{mHz}$ to $10 \mathrm{MHz}$ or higher) provide new information and an insight into the concrete microstructure and hydration ${ }^{19}$. Electrical resistivity is related to the reinforcement corrosion, moisture and heat transfer in concrete $^{20}$.

\section{EXPERIMENTAL SET-UP}

An acoustic-emission measuring system called LOCation ANalyser (LOCAN) 320 made by PAC (France) was used for the measurements. Wide-band sensors (made by the $3 \mathrm{~S}$ Sedlak Company) were used. The sensor output was connected to pre-amplifiers (the PAC Company) with a $2 \mathrm{kHz}$ high-pass filter. The proprietary PAC program package was used to record the acoustic-emission parameters. The acoustic-emission signals were taken by a LOCAN 320 acoustic-emission localizer. The LOCAN 320 system was fine-tuned at a well site and with a sonic-logging tool in the wellbore, with the acoustic threshold set slightly above the background-noise level as measured by LOCAN 320 and the internal gain set according to the manufacturer's recommendations. This device was designed to record and evaluate ultrasonic signals. It was used to analyze and store the acoustic-emission parameters. It can process signals coming from four measuring points. Each recorded event can be characterized with the following acoustic-emission parameters: recording date and time, (maximum) amplitude, acoustic-emission energy, count, rise time and mean frequency ${ }^{21}$.

The impedance of the material under investigation changes in accordance with the structural changes, particularly the water absorption and evaporation. A change in the resistance is obvious. The capacity $C$ of a parallel-plate capacitor is computed with:

$$
C(f)=\varepsilon_{r} \cdot \varepsilon_{0} \cdot \frac{S}{d}
$$

where $\varepsilon_{\mathrm{r}}$ is the relative permittivity, $\varepsilon_{0}$ is the vacuum permittivity $\left(8.854 \cdot 10^{-12} \mathrm{~F} / \mathrm{m}\right), S$ is the measuring-electrode area, $d$ is the distance and $f$ is the frequency. The resistance, $R$, of the electrodes is given by:

$$
R(f)=\rho \cdot \frac{d}{S}
$$

where $\rho$ is the resistivity. Microstructural changes in a material make the material's permittivity change. The permittivity value can also be affected by macrocracks, depending on the frequency ${ }^{22}$.

Two cylindrical steel electrodes of a diameter of $6 \mathrm{~mm}$, buried $65 \mathrm{~mm}$ under the specimen surface, were used for measuring the resistance. To measure the capacitance, two rectangular metal-plate electrodes with dimensions of $25 \mathrm{~mm} \times 45 \mathrm{~mm}$ were applied. All the electrodes were fixed to a plastic slab so that their constant configuration was guaranteed. The electrodes and the temperature-sensor outputs were connected to an automated measuring device. The measurements of the capacitance, the temperature and the impedance were started within $15 \mathrm{~min}$ after the mixture preparation. This phase of the experiment was carried out using a TESLA BM 595 RLCG bridge and a selector switch. The measurement was carried out at selected points with frequencies in the range from $100 \mathrm{~Hz}$ to $20 \mathrm{kHz}$. Each of the electrical quantities (resistance, capacitance, temperature, etc.) was measured separately ${ }^{23}$.

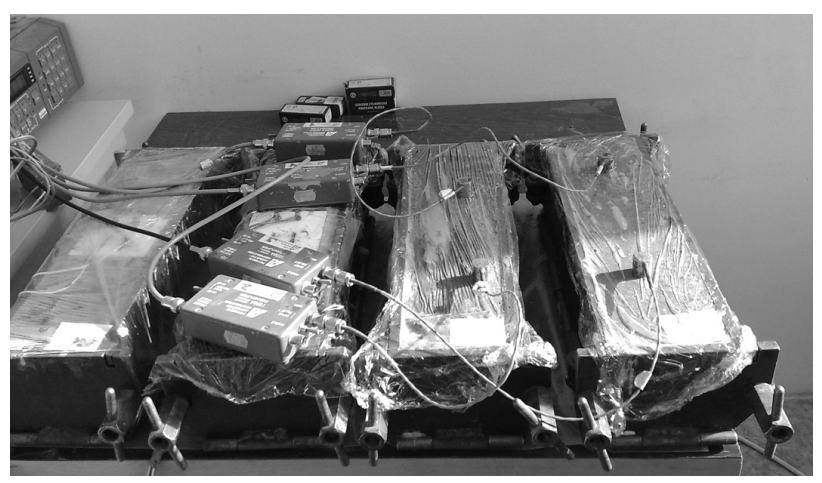

Figure 1: Experimental set-up before unmoulding, (samples S1, S2 tested with the acoustic-emission method and S3, S4 with impedance spectroscopy)

Slika 1: Eksperimentalni sestav pred razdrtjem (vzorca S1, S2 preizkušena z metodo akustične emisije in S3, S4 z impedančno spektroskopijo) 


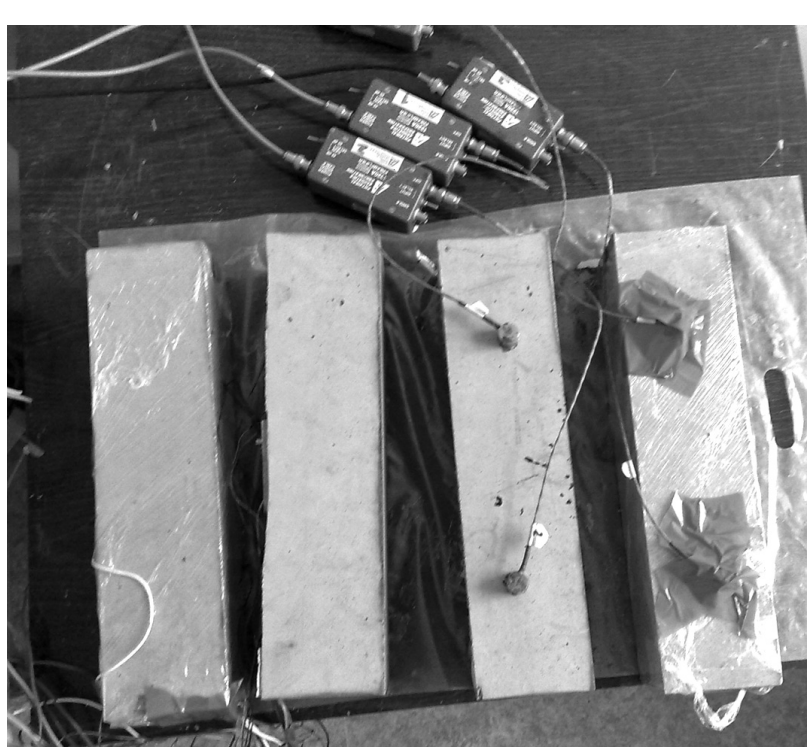

Figure 2: Experimental set-up after unmoulding (sample S1 and S4 are covered, S2 and S3 are uncovered)

Slika 2: Eksperimentalni sestav po razdrtju (vzorca S1 in S4 sta pokrita in S2 ter S3 nepokrita)

Sleeper concrete with a $32 \mathrm{~mm}$ crushed aggregate attained a compression strength of $107 \mathrm{MPa}$. Two of the specimens with dimensions of $100 \mathrm{~mm} \times 100 \mathrm{~mm} \times 400$ $\mathrm{mm}$ were mould cast. Steel-mould upper sides were covered with PE foil (Figure 1). The components of the mixture are shown in Table 1. The mechanical properties of the monitored samples are statistically processed in Table 2. When the specimens were unmoulded, $24 \mathrm{~h}$ after the mixing, one specimen was covered with foil and the other one was not (Figure 2). In Figures 1 and 2, samples S1 and S2 are tested with the acoustic-emission method and samples S3 and S4 with impedance spectroscopy; samples S1 and S4 are covered.

Table 1: Concrete mixture

Tabela 1: Mešanica betona

\begin{tabular}{|l|c|}
\hline \multicolumn{1}{|c|}{ Composition } & Mass, $\mathrm{m} / \mathrm{kg}$ \\
\hline Cement CEM I 42.5R & 390 \\
\hline Water & 125 \\
\hline Plasticizer Stachement 2060 & 4 \\
\hline Sand 0/4 & 700 \\
\hline Coarse aggregate 16/32 & 1275 \\
\hline
\end{tabular}

\section{RESULTS}

The acoustic-emission activities of both samples during hydration, hardening and setting are shown in Figures 3 and 4. After the unmoulding, i.e., at the age of $24 \mathrm{~h}$, when one sample was wrapped and the other one was left without any protection, the acoustic-emission activities were different. The increase in the cumulative acoustic-emission-count curve of the protected sample is lower than that of the sample without protection during the whole $120 \mathrm{~d}$ period, as shown in Figure 4. It should

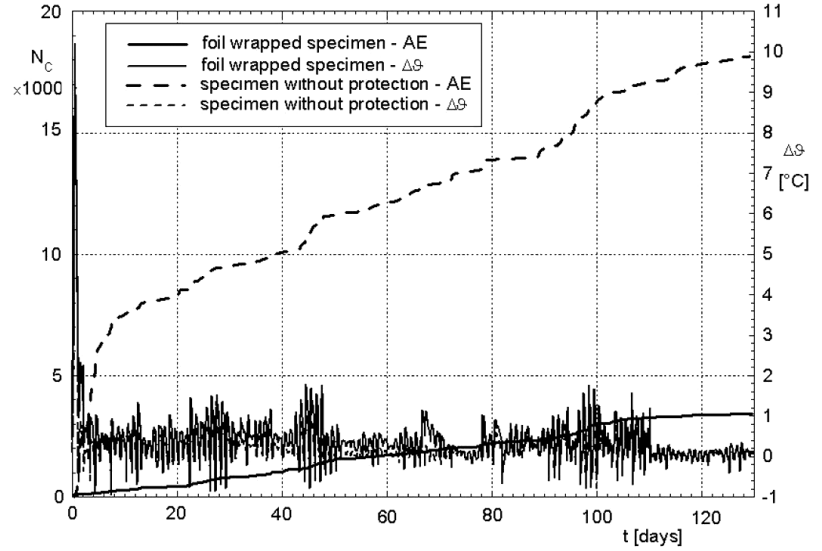

Figure 3: Dependence of cumulative acoustic emission $\left(N_{\mathrm{C}}\right)$ and temperature difference $(\Delta \vartheta)$ on time $(t)$

Slika 3: Odvisnost kumulativne akustične emisije $\left(N_{\mathrm{C}}\right)$ in temperaturne razlike $(\Delta \vartheta)$ od časa $(t)$

be noted that the acoustic-emission signals were picked up six hours after the mixtures were made.

The temperature of the samples after the unmoulding was kept close to the ambient temperature (Figure 3). The basic changes in the concrete structure during the hydration relate to the temperature peak, in this case after $12 \mathrm{~h}$, as shown in Figure 4..$^{24}$ The temperature curves for both samples are the same as before the unmoulding, i.e., slightly different ${ }^{25}$.

Electrical measurements show a higher resistivity and a lower capacity, i.e., a higher capacitance of the specimen without protection after the unmoulding (Figure 5).

Different changes of both samples are also shown in Figure 6. On the first day the frequency characteristics of resistance $(R)$ and capacitance $\left(X_{\mathrm{C}}\right)$ are the same, but thereafter they are different. There are three types of curves described in the legend in Figure 6. Each curve, as described on the curve at the $6^{\text {th }} \mathrm{h}$, consists of eight points whose frequencies from the left-hand side of the horizontal axis are $100 \mathrm{~Hz}, 200 \mathrm{~Hz}, 400 \mathrm{~Hz}, 1 \mathrm{kHz}$,

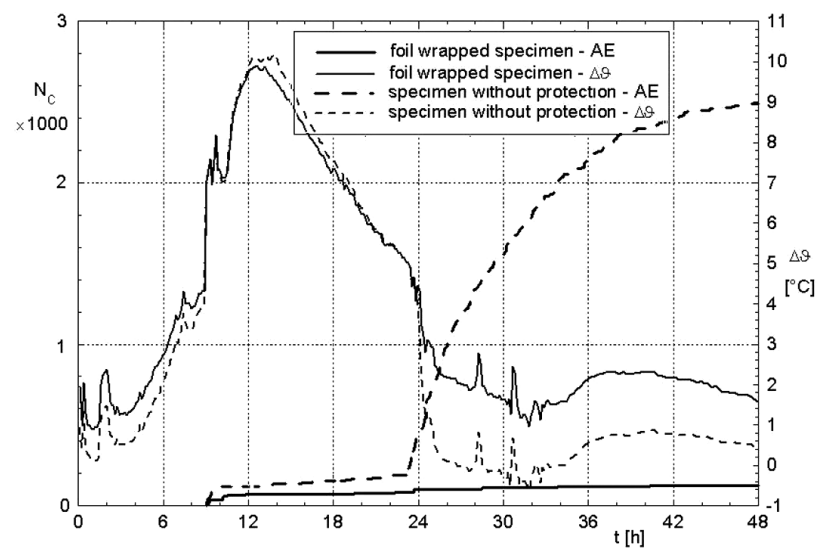

Figure 4: Details of the curves plotted in Figure 3 for the first two days

Slika 4: Detajl krivulje s slike 3 za prva dva dneva 


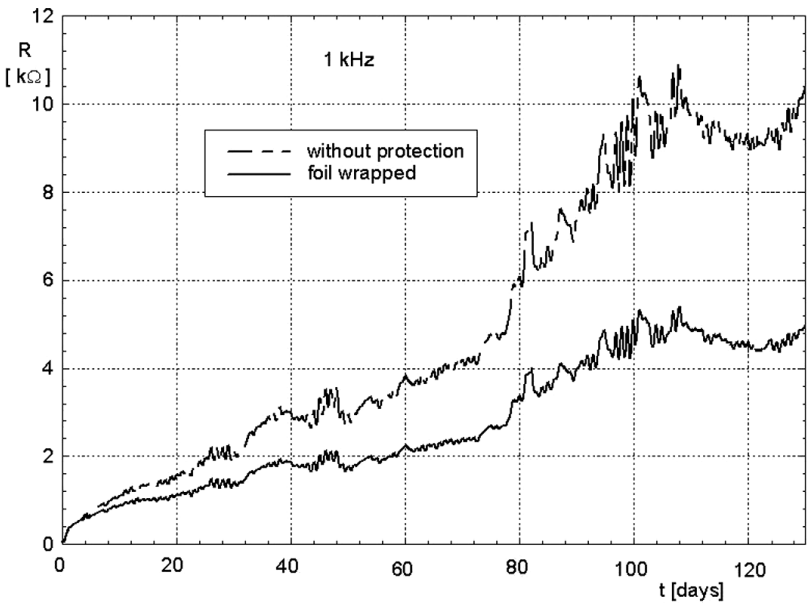

Figure 5: Dependence of electrical resistance $(R)$ and capacity $(C)$ on time $(t)$

Slika 5: Odvisnost električne upornosti $(R)$ in kapacitete $(C)$ od časa $(t)$

$2 \mathrm{kHz}, 4 \mathrm{kHz}, 10 \mathrm{kHz}$ and $20 \mathrm{kHz}{ }^{26}$. It is clear that the shapes of the curves are different after the unmoulding, therefore, the curves of both samples are the same on the first day (in Figure 6 marked with downward-pointing triangles).

Table 2: Main parameters of samples

Tabela 2: Glavni parametri vzorcev

\begin{tabular}{|l|c|c|c|}
\hline & Units & Mean & Deviation \\
\hline Compressive strength & $\mathrm{MPa}$ & 107 & 5 \\
\hline Flexural strength & $\mathrm{MPa}$ & 10.0 & 0.2 \\
\hline $\begin{array}{l}\text { Modulus of elasticity } \\
\text { (bending) }\end{array}$ & $\mathrm{GPa}$ & 37 & 3 \\
\hline Fracture toughness & $\mathrm{MPa} \mathrm{m}{ }^{1 / 2}$ & 1.8 & 0.4 \\
\hline Fracture energy & $\mathrm{J} / \mathrm{m}^{2}$ & 200 & 10 \\
\hline
\end{tabular}

\section{CONCLUSION}

The acoustic-emission method and impedance spectroscopy are powerful tools for determining the development of microcracks during the hardening and setting of concrete. It can be assumed that higher numbers of microcracks cause higher numbers of acoustic-emission events. The dependence of a cumulative acoustic-emission activity on the time shows the necessity of curing the concrete during its whole lifetime, especially during intense hydration and hardening. The big differences between the acoustic-emission activities of wrapped and unprotected samples clearly indicate the essentiality of the high moistness of hardened concrete. The number of microcracks in cement mortar affects the resulting mechanical properties of concrete.

Impedance, or dielectric, spectroscopy together with acoustic emission can also help with the monitoring and a detailed description of lifetime behaviours of concrete specimens during hydration.

As the acoustic emission (Figure 3) and the impedance (Figure 5) history of both samples are similar, the

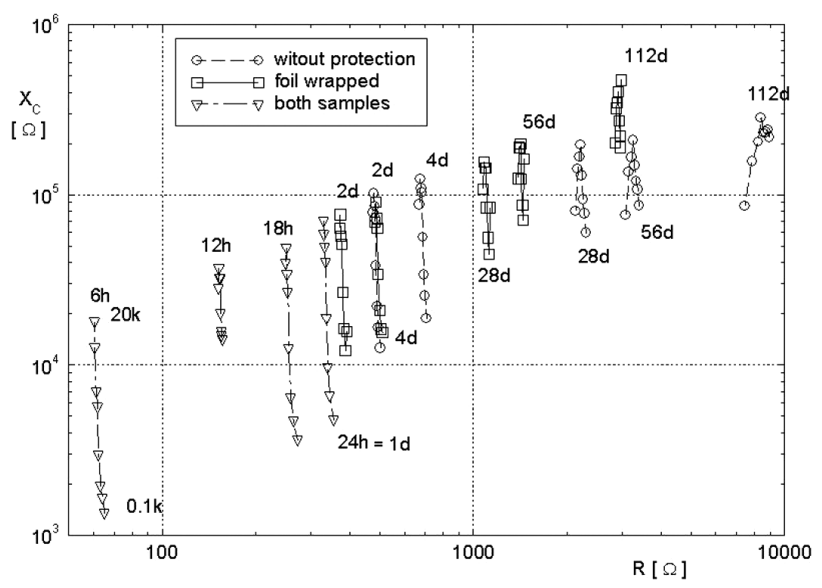

Figure 6: Dependence of capacitance $\left(X_{\mathrm{C}}\right)$ on resistance $(R)$ Slika 6: Odvisnost kapacitivnosti $\left(X_{\mathrm{C}}\right)$ od upornosti $(R)$

number of microcracks is higher in the samples without foil, which means that the curing of concrete during an early age is necessary.

\section{Acknowledgement}

This paper has been worked out under the project No. LO1408 "AdMaS UP - Advanced Materials, Structures and Technologies", supported by Ministry of Education, Youth and Sports under the "National Sustainability Programme I" and under the project No. 13-18870S "Assessment and Prediction of the Concrete Cover Layers Durability" supported by Czech Science Foundation.

\section{REFERENCES}

${ }^{1}$ G. Venkiteela, Z. H. Sun, H. Najm, Journal of Materials in Civil Engineering, 25 (2013) 2, 30-38, doi:10.1061/(ASCE)MT.19435533.0000528

${ }^{2}$ W. Chen, Y. Li, P. L. Shen, Z. H. Shui, Journal of Nondestructive Evaluation, 32 (2013) 3, 228-237, doi:10.1007/s10921-013-0175-y

${ }^{3}$ I. M. Nikbin, M. Dehestani, M. H. A. Beygi, M. Rezvani, Construction and Building Materials, 59 (2014), 144-150, doi:10.1016/ j.conbuildmat.2014.02.008

${ }^{4}$ Q. Xua, J. M. Ruiza, J. Hub, K. Wangc, R. O. Rasmussena, Thermochimica Acta, 512 (2011), 76-85, doi:10.1016/j.tca.2010.09.003

${ }^{5}$ W. M. Hale, T. D. Bush, B. W. Russell, S. F. Freyne, Journal of the Transportation Research Board, 1914 (2005), 97-104

${ }^{6}$ T. Nishizawa, T. Fukuda, S. Matsuno, K. Himeno, Transportation Research Record, 1525 (1996), 35-43, doi:10.3141/1525-05

${ }^{7}$ M. Gawlicki, W. Nocun-Wczelik, L. Bak, Journal of Thermal Analysis and Calorimetry, 100 (2010), 571-576, doi:10.1007/s10973009-0158-5

${ }^{8}$ K. V. D. Abeele, W. Desadeleer, G. D. Schutter, M. Wevers, Cement and Concrete Research, 39 (2009), 426-432, doi:10.1016/ j.cemconres.2009.01.016

${ }^{9}$ H. W. Reinhardt, C. U. Grosse, A. T. Herb, Materials and Structures, 33 (2000) 233, 581-583, doi:10.1007/BF02480539

${ }^{10}$ V. A. Aleshin, K. V. D. Abeele, Journal of the Mechanics and Physics of Solids, 55 (2007) 2, 366-390, doi:10.1016/j.jmps.2006.07.002 


\section{PAZDERA et al.: MONITORING EARLY-AGE CONCRETE WITH THE ACOUSTIC-EMISSION METHOD ...}

${ }^{11}$ S. F. Huang, M. M. Li, D. Y. Xu, M. J. Zhou, S. H. Xie, X. Cheng, Research in Nondestructive Evaluation, 24 (2013) 4, 202-210, doi:10.1080/09349847.2013.789949

${ }^{12}$ I. Gabrijel, D. Mikulic, N. Bijelic, Tehnicki Vjesnik-Technical Gazette, 17 (2010) 4, 493-497

${ }^{13}$ K. Ohno, M. Ohtsu, Construction and Building Materials, 24 (2010), 2339-2346, doi:10.1016/j.conbuildmat.2010.05.004

${ }^{14}$ P. Lura, J. Couch, O. M. Jensen, J. Weiss, Cement and Concrete Research, 39 (2009) 10, 861-867, doi:10.1016/j.cemconres.2009. 06.015

${ }^{15}$ M. Tasic, Z. Andic, A. Vujovic, P. Jovanic, Mater. Tehnol., 44 (2010) 6, 397-401

${ }^{16}$ M. Marinsek, Mater. Tehnol., 43 (2009) 2, 79-84

${ }^{17}$ Y. M. Kim, J. H. Lee, S. H. Hong, Cement and Concrete Research, 33 (2003) 3, 299-304, doi:10.1016/S0008-8846(02)00944-4

${ }^{18}$ K. B. Sanish, N. Neithalath, M. Santhanam, Construction and Building Materials, 49 (2013), 288-297, doi:10.1016/j.conbuildmat. 2013.08.038

${ }^{19}$ J. M. Cruz, I. C. Fita, L. Soriano, J. Paya, M. V. Borrachero, Cement and Concrete Research, 50 (2013), 51-61, doi:10.1016/j.cemconres. 2013.03.019
${ }^{20}$ R. Ranade, J. Zhang, J. P. Lynch, V. C. Li, Cement and Concrete Research, 58 (2014), 1-12, doi:10.1016/j.cemconres.2014.01.002

${ }^{21}$ C. Jomdecha, A. Prateepasen, P. Kaewtrakulpong, NDT \& E International, 40 (2007) 8, 584-593, doi:10.1016/j.ndteint.2007.05.003

${ }^{22}$ S. R. Mahapatra, V. Sridhar, D. K. Tripathy, Polymer Composites, 29 (2008) 5, 465-472, doi:10.1002/pc.20421

${ }^{23}$ M. Lunak, I. Kusak, L. Pazdera, L. Topolar, V. Bilek, Proc. of the 48th International Scientific Conference on Experimental Stress Analysis EAN 2010, Velke Losiny, Czech Republic, 2010, 233-240, Code 106809

${ }^{24}$ A. Feylessoufi, F. C. Tenoudji, V. Morin, P. Richard, Cement and Concrete Research, 31 (2001) 11, 1573-1579, doi:10.1016/S00088846(01)00602-0

${ }^{25}$ M. H. Cornejo, J. Elsen, H. Baykara, C. Paredes, European Journal of Environmental and Civil Engineering, 18 (2014) 6, 629-651, doi:10.1080/19648189.2014.897005

${ }^{26}$ J. M. Deus, B. Diaz, L. Freire, X. R. Novoa, Electrochimica Acta, 131 (2014), 106-115, doi:10.1016/j.electacta.2013.12.012 